\title{
Mitigating heavy metal accumulation into rice (Oryza sativa L.) using biochar amendment - a field experiment in Hunan, China
}

\author{
Ruilun Zheng • Zheng Chen • Chao Cai • Baiqing Tie • \\ Xiaoli Liu • Brian J. Reid • Qing Huang • Ming Lei • \\ Guoxin Sun • Edita Baltrẻnaitė
}

Received: 10 November 2014 / Accepted: 23 February 2015 / Published online: 22 March 2015

(C) Springer-Verlag Berlin Heidelberg 2015

\begin{abstract}
A field experiment was conducted to investigate the effect of bean stalk (BBC) and rice straw (RBC) biochars on the bioavailability of metal(loid)s in soil and their accumulation into rice plants. Phytoavailability of Cd was most dramatically influenced by biochars addition. Both biochars significantly decreased $\mathrm{Cd}$ concentrations in iron plaque (35-81\%), roots (30-75\%), shoots (43-79\%) and rice grain (26-71\%). Following biochars addition, Zinc concentrations in roots and shoots decreased by $25.0-44.1$ and $19.9-44.2 \%$, respectively, although no significant decreases were observed in iron plaque and rice grain. Only $\mathrm{RBC}$ significantly reduced $\mathrm{Pb}$
\end{abstract}

Responsible editor: Elena Maestri

R. Zheng $\cdot$ Z. Chen $\cdot$ G. Sun $(\bowtie)$

Research Center for Eco-Environmental Sciences, Chinese Academy

of Sciences, Beijing 100085, People's Republic of China

e-mail: gxsun@rcees.ac.cn

R. Zheng

Research and Development Center for Grasses and Environment, Beijing Academy of Agriculture and Forestry Sciences,

Beijing, 100097, People's Republic of China

C. Cai $\cdot$ Q. Huang

Institute of Urban Environment, Chinese Academy of Sciences,

Xiamen 361003, People's Republic of China

B. Tie $\cdot$ X. Liu $\cdot$ M. Lei

College of Resource and Environment, Hunan Agricultural

University, Changsha 410128, People's Republic of China

B. J. Reid

School of Environmental Sciences, University of East Anglia,

Norwich Research Park, Norwich NR4 7TJ, UK

E. Baltrènaitè

Institute of Environmental Protection, Vilnius Gediminas Technical

University, Sauletekio al. 11, Vilnius 10223, Lithuania concentrations in iron plaque $(65.0 \%)$ and roots $(40.7 \%)$. However, neither biochar significantly changed $\mathrm{Pb}$ concentrations in rice shoots and grain. Arsenic phytoavailability was not significantly altered by biochars addition. Calculation of hazard quotients (HQ) associated with rice consumption revealed $\mathrm{RBC}$ to represent a promising candidate to mitigate hazards associated with metal(loid) bioaccumulation. RBC reduced Cd HQ from a 5.5 to 1.6. A dynamic factor's way was also used to evaluate the changes in metal(loid) plant uptake process after the soil amendment with two types of biochar. In conclusion, these results highlight the potential for biochar to mitigate the phytoaccumulation of metal(loid)s and to thereby reduce metal(loid) exposure associated with rice consumption.

Keywords Biochar · Metal(loid) · Rice (Oryza sativa L.) · Soil contamination $\cdot$ Hazard quotient

\section{Introduction}

Biochar is receiving increasing attention due to its benefits in agricultural and environmental contexts. There is growing evidence that the application of biochar to soil has the potential to mitigate global warming (Lehmann 2007), improve soil quality (Fellet et al. 2011), reduce the bioavailability of organic contaminants ( $\mathrm{Li}$ et al. 2013), increase nutrient and water retention capacity of soil (Abel et al. 2013; Zheng et al. 2013a), and thereby increase crop yield (Zhang et al. 2012).

Rice is recognized as a staple global food with over 400 million metric tons of milled rice being consumed each year. Approximately half of the world's population is reliant upon rice for sustenance (Zhu et al. 2008). Several studies have reported enhanced plant growth and rice grain yield following 
biochar addition to soil (Dong et al. 2013; Khan et al. 2013). These findings are clearly important in the context of food security and provisioning for an increasing global population. However, rice is also recognized as a major dietary source for metal(loid) exposure (Zhu et al. 2008; Williams et al. 2009). Many studies, from various countries, have reported metal(loid) concentrations that exceed guidance values (Herawati et al. 2000; Wang et al. 2001; Cheng et al. 2006b; Meharg et al. 2009; Rogan et al. 2009). The exposure to metal(loid)s through the consumption of contaminated rice brings elevated risk to human health. Given the global importance of rice as a food stuff there is a pressing need to establish means or technologies to mitigate the phytoaccumulation of metal(loid)s into rice. With biochar amendments expected to become commonplace, to sequester carbon and increase crop yield, there stands the possibility of ancillary benefits in terms of reduced metal(loid) levels in rice grain and, as a consequence, reduced dietary metal(loid) exposure associated with rice consumption. Such a proposition is not unfounded; several studies have already established the ability of biochar to immobilize metals, such as $\mathrm{Cd}, \mathrm{Zn}, \mathrm{Cu}$, and $\mathrm{Pb}$, in the soil and to thereby reduce their accumulations within plants. Incorporation of biochars into soil caused significant immobilization of $\mathrm{Cd}, \mathrm{Cu}$, and $\mathrm{Pb}$ in a shooting range soil and thereby reducing the accumulation of these metals in Indian mustard (Park et al. 2011). Further to these studies, large decreases in $\mathrm{Cd}, \mathrm{Zn}$, and $\mathrm{Pb}$ accumulation in rice plant grown in a historically contaminated soil after biochar additions were observed in our previous pot study (Zheng et al. 2012). Biochar amendment to soil has recently been reported to reduce $\mathrm{Cd}$ accumulation in rice plant from $\mathrm{Cd}$ contaminated rice paddies (Cui et al. 2011; Bian et al. 2013). However, not all metal(loid)s have shown such positive response to biochar amendment to soil. Arsenic concentrations in porewater following biochar addition to soil (Beesley et al. 2010) were shown to increase $>30$-folds, while our previous pot study (Zheng et al. 2012) indicated considerable (threefold) increase in phytoaccumulation of As into rice shoots.

Although many studies have reported the effect of biochar on the immobilization of heavy metals in soils, information is still lacking regarding the effectiveness of biochar amendment for multielemental immobilization and accumulation into edible plant parts under field conditions. The intention of this research was to consider the potential of biochar to afford dual benefits of improved grain yield and improved food safety (through the reduction in metal(loid) phytoaccumulation). Thus, the present study was conducted (i) to investigate the influence of biochar additions on the mobility of metal(loid)s in a multielemental contaminated paddy field soil; (ii) to investigate their accumulations in rice plants; (iii) to calculate changes in metal(loid) intake and hazard quotients (HQ) associated with rice consumption; and (iv) to compare the effects of biochars made from different parent materials (bean stalk and rice straw).

\section{Materials and methods}

Study area and biochar description

The field experiment was carried out at a rice field in Xinma Town, Zhuzhou, Hunan Province, China (N2750', E113 $02^{\prime}$ ) and was initiated in 2011. The paddy field soil was historically contaminated with metal(loid)s, due to inundation with waste water, over the course of about 50 years, from a nearby galvanizing mill.

Biochar was made from bean stalk (BBC) and rice straw (RBC). Each type of biomass was charred in a kiln at $500{ }^{\circ} \mathrm{C}$ for $8 \mathrm{~h}$ and then ground to pass through sieves with 2 $\mathrm{mm}$ mesh. Selected physicochemical properties of the field soil and biochars are presented in Table 1.

\section{Experimental design}

There were three treatments in this experiment: control (no addition of biochar) and addition of BBC or RBC. Three plots $(1.2 \times 1.2 \mathrm{~m})$ were produced for each treatment type. BBC and $\mathrm{RBC}(<2 \mathrm{~mm})$ were added into the soil at a rate of 20 tons $\mathrm{ha}^{-1}$, respectively, and mixed thoroughly with top soil (0-20 cm depth) via manual plowing. Synthetic fertilizers were applied as basal fertilizers at $150 \mathrm{~kg} \mathrm{P}_{2} \mathrm{O}_{5} \mathrm{ha}^{-1}, 150 \mathrm{~kg}$ $\mathrm{K}_{2} \mathrm{O} \mathrm{ha}^{-1}$, and $150 \mathrm{~kg} \mathrm{~N} \mathrm{ha}^{-1}$. Following a period of 2 weeks, rice seedlings (Oryza sativa L.), which had been raised for 4 weeks in clean soil were transplanted into experimental plots. Rice used here was a traditional local cultivar named Zhongyou 978 . Urea was supplied $\left(100 \mathrm{~kg} \mathrm{ha}^{-1}\right) 2$ weeks after transplanting of the rice seedlings. The water management was as follows: at tillering stage, a regime of shallow water

Table 1 Physicochemical properties and elemental concentrations in soil, BBC, and RBC

\begin{tabular}{llllll}
\hline & Soil & Background soil & BBC & RBC & Regulatory limits \\
\hline $\mathrm{pH}$ & 6.1 & 9.2 & 10.5 & \\
$\mathrm{CEC}$ & 12.5 & 27.5 & 32.1 & \\
$\mathrm{TC}(\%)$ & 1.4 & 44.5 & 27.4 & \\
$\mathrm{TN}(\%)$ & 0.15 & 1.85 & 1.26 \\
$\mathrm{Cd}\left(\mu \mathrm{g} \mathrm{g}^{-1}\right)$ & 4.7 & $0.126^{\mathrm{a}}$ & 0.15 & 0.10 & $0.3^{\mathrm{b}}$ \\
$\mathrm{Zn}\left(\mu \mathrm{g} \mathrm{g}^{-1}\right)$ & 360 & $94.4^{\mathrm{a}}$ & 265.7 & 255.4 & $200^{\mathrm{b}}$ \\
$\mathrm{Pb}\left(\mu \mathrm{g} \mathrm{g}^{-1}\right)$ & 124 & $29.7^{\mathrm{a}}$ & 14.0 & 12.8 & $250^{\mathrm{b}}$ \\
$\mathrm{As}\left(\mu \mathrm{g} \mathrm{g}{ }^{-1}\right)$ & 34 & $15.7^{\mathrm{a}}$ & 0.14 & 0.79 & $30^{\mathrm{b}}$ \\
$\mathrm{K}(\%)$ & - & 5.0 & 7.9 & \\
$\mathrm{P}(\%)$ & - & 0.37 & 0.46 \\
\\
\hline CEC cation exchange capacity (cmol kg $\left.{ }^{-1}\right)$ \\
a Concentrations in background soil of Hunan, China (CNEMC 1990). \\
b Environmental quality standard for agricultural soils of China, \\
GB15618-1995
\end{tabular}


submerged irrigation and humid irrigation was alternated. Afterwards, the flooded land was drained for about a week before the jointing stage. Thereafter, an intermittent shallow water submerged, irrigation regime was used during the jointingbooting stage and the filling stage, and the land was unwatered for a week before harvest.

\section{Sampling and chemical analysis}

Samples including top soil and roots, shoots, and ears of mature rice were taken after 4 months growth. Soil samples were taken at five random points (away from the edge of experimental plot) in each of the replicated plots. These five samples were combined to give a composite sample for the plot. Soil samples were air-dried, crushed, and sieved with 2-mm mesh. Shoots were cut at the soil surface, washed with deionized water; fresh weight were recorded and dried at $70{ }^{\circ} \mathrm{C}$ for $48 \mathrm{~h}$. The corresponding root samples $(0-20 \mathrm{~cm}$ depth) with attached soil were taken and washed gently with deionized water through a sieve to dislodge soil from the roots. The clean-washed root samples were stored at $2{ }^{\circ} \mathrm{C}$ for further treatments. The corresponding ear samples were washed with deionized water, dried at $70{ }^{\circ} \mathrm{C}$ for $48 \mathrm{~h}$, and then separated into husk and rice grain using a rice sheller.

Iron plaque was extracted from fresh root surfaces using dithionite-citrate-bicarbonate (DCB) solution containing $0.03 \mathrm{M}$ sodium citrate and $0.125 \mathrm{M}$ sodium bicarbonate, with the addition of $0.02 \mathrm{~g}$ sodium dithionite per milliliter (Taylor and Crowder 1983; Liu et al. 2004). The root sample per cluster was immersed in DCB solution $(200 \mathrm{ml})$ at $25^{\circ} \mathrm{C}$ for $60 \mathrm{~min}$, and then rinsed three times with deionized water. Rinse water was poured into the DCB extracts and the total volume was made up to $250 \mathrm{ml}$ with deionized water. The final solution was passed through a $0.45-\mu \mathrm{m}$ nylon filter and refrigerated at $2{ }^{\circ} \mathrm{C}$ until analysis (Liu et al. 2004). After extraction by DCB solution, fresh roots were oven-dried at $70{ }^{\circ} \mathrm{C}$ for $48 \mathrm{~h}$.

Metal(loid) concentrations in dried plant samples were determined as follows. Samples were ground to a fine powder, weighed into $50 \mathrm{ml}$ polyethylene centrifuge tubes, and digested with concentrated $\mathrm{HNO}_{3}(2 \mathrm{ml})$ in a microwave digestor (Sun et al. 2008).

Finely ground $(<0.149 \mathrm{~mm})$ soil and biochar samples were digested with $\mathrm{HNO}_{3}-\mathrm{HCl}-\mathrm{HClO}_{4}(3: 1: 1)$ for determination of total element concentrations. Available metal(loid) concentrations in the soil were assessed using $1 \mathrm{M} \mathrm{NH}_{4} \mathrm{NO}_{3}$ as an extractant $(1: 2.5 \mathrm{w} / \mathrm{v}) .1 \mathrm{M} \mathrm{NH}_{4} \mathrm{NO}_{3}(25 \mathrm{ml})$ was added to soil samples $(10 \mathrm{~g})$ contained within $50 \mathrm{ml}$ flask and shaken for $2 \mathrm{~h}$. Elements in dissolved samples and extracts were determined using inductively coupled plasma mass spectroscopy (ICP-MS, 7500a, Agilent Technologies, USA) for Cd, Zn, Pb, and As with indium isotopes (In115) as internal standards $\left(10 \mu \mathrm{g} \mathrm{l}^{-1}\right)$, and ICP optical emission spectroscopy (ICPOES, Optima 2000, Perkin-Elmer, USA) for P and K. Certified reference material (CRM) GBW07603 (bush twigs and leaves), GBW10010 (GSB-1; rice), spikes, and blanks were used for quality control. The recovery of the elements determined ranged from 82 to $115 \%$.

The cation exchange capacity (CEC) was determined referring to modified barium chloride compulsive exchange method (Lee et al. 2010). Total carbon (TC) and nitrogen (TN) analyses of soil and biochar were conducted on a solid TC/ TN analyzer (Vario EL III, Elementar Analysen systeme, Germany).

Daily intake of metal(loid)s and hazard quotient (HQ)

The estimated daily intake (EDI) of metal(loid)s through consumption of rice was determined using the following equation (Eq. 1):

$\mathrm{EDI}=\frac{\mathrm{IR}_{\text {Rice }} \times \mathrm{C}_{\mathrm{PTEs}}}{\mathrm{BW}}$

where $\mathrm{IR}_{\text {Rice, }} \mathrm{C}_{\mathrm{PTEs}}$, and $\mathrm{BW}$ represent the rice intake rate ( $\mathrm{kg} \mathrm{day}^{-1}$; $218 \mathrm{~g} \mathrm{day}^{-1}$; Meharg et al. 2009), metal(loid) concentrations in rice, and average body weight $(70 \mathrm{~kg})$.

The hazard quotient (HQ) indices for the metal(loid)s in rice was calculated using the equation detailed by the U.S. Environmental Protection Agency (USEPA 2014).

$\mathrm{HQ}=\frac{\mathrm{EDI}}{\mathrm{RfD}}$

where RfD represents the oral reference dose. $\mathrm{RfD}$ for $\mathrm{Cd}, \mathrm{Zn}$, $\mathrm{Pb}$, and As were $1,300,3.5$, and $0.3 \mathrm{\mu g} \mathrm{kg}^{-1}$ day $^{-1}$, respectively (USEPA 2014).

Dynamic factor (DF) of metal(loid) bioavailability $\left(\mathrm{BIO}_{\mathrm{dyn}}\right)$ and bioaccumulation $\left(\mathrm{BA}_{\mathrm{dyn}}\right)$

The DF of metal(loid) bioavailability $\left(\mathrm{BIO}_{\mathrm{dyn}}\right)$ in soil and that of metal(loid) bioaccumulation $\left(\mathrm{BA}_{\mathrm{dyn}}\right)$ in rice roots $\left(\mathrm{BA}_{\text {dyn_roots }}\right)$, shoots $\left(\mathrm{BA}_{\mathrm{dyn} \_ \text {shoots }}\right)$, and grain $\left(\mathrm{BA}_{\mathrm{dyn} \_ \text {grain }}\right)$ were calculated using the following Eq. 2, Eq. 3, Eq. 4, and Eq. 5, respectively, referring to Baltrènaite et al. (2012, 2015):

$$
\begin{aligned}
\mathrm{BIO}_{\mathrm{dyn}}= & \frac{[M]_{\mathrm{bav}} \text { in } \mathrm{BBC} \text { or RBC treatment }}{[M]_{\text {soil }} \text { in } \mathrm{BBC} \text { or RBC treatment }} \\
& \times \frac{[M]_{\text {soil }} \text { in control }}{[M]_{\mathrm{bav}} \text { in control }}
\end{aligned}
$$




$$
\begin{aligned}
\mathrm{BA}_{\text {dyn_roots }}= & \frac{[M]_{\text {root }} \text { in } \mathrm{BBC} \text { or RBC treatment }}{[M]_{\text {soil }} \text { in BBC or RBC treatment }} \\
& \times \frac{[M]_{\text {soil }} \text { in control }}{[M]_{\text {root }} \text { in control }}
\end{aligned}
$$

$$
\begin{aligned}
\mathrm{BA}_{\text {dyn_shoots }}= & \frac{[M]_{\text {shoot }} \text { in } \mathrm{BBC} \text { or RBC treatment }}{[M]_{\text {soil }} \text { in } \mathrm{BBC} \text { or RBC treatment }} \\
& \times \frac{[M]_{\text {soil }} \text { in control }}{[M]_{\text {shoot }} \text { in control }}
\end{aligned}
$$

$$
\begin{aligned}
\mathrm{BA}_{\text {dyn_grain }}= & \frac{[M]_{\text {grain }} \text { in } \mathrm{BBC} \text { or RBC treatment }}{[M]_{\text {soil }} \text { in } \mathrm{BBC} \text { or RBC treatment }} \\
& \times \frac{[M]_{\text {soil }} \text { in control }}{[M]_{\text {grain }} \text { in control }}
\end{aligned}
$$

where $[M]_{\text {bav }}$ and $[M]_{\text {soil }}$ represent $\mathrm{NH}_{4} \mathrm{NO}_{3}$-extractable metal(loid) concentration and total metal(loid) concentration in soil, respectively. $[M]_{\text {roots }},[M]_{\text {shoots }}$, and $[M]_{\text {grain }}$ represent metal(loid) concentration in roots, shoots, and grain of rice plant, respectively. All data used were means of four replicates for each treatment, and the concentration units were consistent in milligrams per kilogram.

\section{Statistical analysis}

All data were subjected to one-way analysis of variance (ANOVA). Significant effects were compared using the Tukey's test $(p<0.05)$. Statistical analysis was performed using the SPSS 16.0 software (SPSS, USA).

\section{Results}

Characteristics of the soil and biochars

The soil used in this study was moderately acidic $(\mathrm{pH} 6.1)$. Concentrations of metal(loid)s in the soil were elevated with respect to background soil concentrations: $\mathrm{Cd}(\times 37.3), \mathrm{Zn}$ $(\times 3.8), \mathrm{Pb}(\times 4.2)$, and As $(\times 2.2)($ Table 1$)$. Concentrations of $\mathrm{Cd}, \mathrm{Zn}$, and As also elevated by factors of 15.7, 1.8, and 1.1, respectively, above guidance values for agricultural soil regulations of China (GB15618-1995). Only $\mathrm{Pb}$ concentrations were lower $(50 \%)$ than the agricultural soil regulation value.

$\mathrm{BBC}$ and $\mathrm{RBC}$ had high $\mathrm{pH}$ and $\mathrm{CEC}$ and also high carbon levels (Table 1). These were in agreement with other studies
(Atkinson et al. 2010; Hale et al. 2011; Yuan et al. 2011). In addition, BCs used here also contained nutrients such as $\mathrm{K}$ (5.0-7.9\%), P (0.4-0.5\%), and N (1.3-1.9\%) (Table 1). Properties of biochar varied depending on the feedstock material (Table 1). RBC was more alkaline ( $\mathrm{pH} 10.5)$ than $\mathrm{BBC}$ (pH 9.2). CEC (32.1 $\left.\mathrm{cmol} \mathrm{kg}^{-1}\right), \mathrm{K}(7.9 \%)$, and P (0.46\%) concentrations of RBC were $16.7,58$, and $24.3 \%$ higher than that of $\mathrm{BBC}$, respectively, whereas TC $(27.4 \%)$ and $\mathrm{TN}$ $(1.26 \%)$ concentrations of $\mathrm{RBC}$ were 38.4 and $31.9 \%$ lower than that of BBC. The difference in properties between BBC and $\mathrm{RBC}$ are consistent with reports that account chemical constituents in BCs to vary with feedstock and pyrolysis conditions used (Atkinson et al. 2010).

Concentrations of $\mathrm{Cd}, \mathrm{Pb}$, and $\mathrm{As}$ in both $\mathrm{RBC}$ and $\mathrm{BBC}$ were much lower than in the soil used in this study (Table 1). However, concentrations of $\mathrm{Zn}$ in $\mathrm{RBC}$ and $\mathrm{BBC}$ were similar to those in soil. While there are no regulatory limits in place for biochar, the concentrations of all four metal(loid)s were much lower than the Chinese regulation limit set for sludge to be used for agriculture (GB18918-2002). Cd concentration in $\mathrm{RBC}$ and $\mathrm{BBC}$ were an order of magnitude lower than maximum values reported for a range of biochars (Freddo et al. 2012), while $\mathrm{Zn}, \mathrm{Pb}$ and As fell within a factor of 3 .

\section{Influence of biochar on biomass yield}

The essential plant nutrients in biochar (Table 1) are usually conducive to crop production (Park et al. 2011; Uzoma et al. 2011). In our present study, shoot weights were increased though not significantly $(p>0.05)$. Grain weights were increased and decreased in BBC and RBC treatments by 57.5 and $7.4 \%$, respectively, but these changes were also not significant ( $p>0.05$; Table 3$)$. RBC addition significantly increased $\mathrm{K}$ and $\mathrm{P}$ concentrations of rice shoot by 20.3 and $29.6 \%$, respectively, but this outcome was not observed in the BBC treatment. These results indicate the potential to improve plant growth is dependent on type of $\mathrm{BC}$ applied.

$\mathrm{NH}_{4} \mathrm{NO}_{3}$-extractable concentrations of metal(loid)s

$\mathrm{NH}_{4} \mathrm{NO}_{3}$ extractable fractions of metal(loid)s represented a very small portion of the total metal loadings: $\mathrm{Cd}(<3 \%)$, $\mathrm{Zn}(<0.6 \%), \mathrm{Pb}(<0.1 \%)$, and $\mathrm{As}(<0.1 \%)$. Biochar addition significantly decreased initial $\mathrm{NH}_{4} \mathrm{NO}_{3}$-extractable concentrations of soil $\mathrm{Cd}, \mathrm{Zn}$, and $\mathrm{Pb}\left(0.14,2.03\right.$, and $\left.0.15 \mu \mathrm{g} \mathrm{g}^{-1}\right)$ by 66.0-90.1\%, 73.1-92.2\%, and 74.1-91.0\%, respectively (Fig. 1). Given the concentrations of $\mathrm{Cd}, \mathrm{Zn}$, and $\mathrm{Pb}$ in BBC, RBC, and soil (Table 1) and the rate of application these changes cannot be attributed to a dilution effect. Rather they reflect biochar induced changes to metal(loid) partitioning (see "Discussion"). In contrast to $\mathrm{Cd}, \mathrm{Zn}$, and $\mathrm{Pb}$, extractable As concentration $\left(0.02 \mu \mathrm{g} \mathrm{g}^{-1}\right)$ increased by up to $73.3 \%$ (Fig. 1). Again, these changes are proposed to reflect 
Fig. $1 \mathrm{NH}_{4} \mathrm{NO}_{3}$-extractable concentrations of $\mathrm{Cd}, \mathrm{Zn}, \mathrm{Pb}$, and As in un-amended soils (white), $\mathrm{BBC}$ treatments (grey), and RBC treatments (black). Different letters above bars indicate significant difference at $p<0.05$ between treatments $(n=4)$

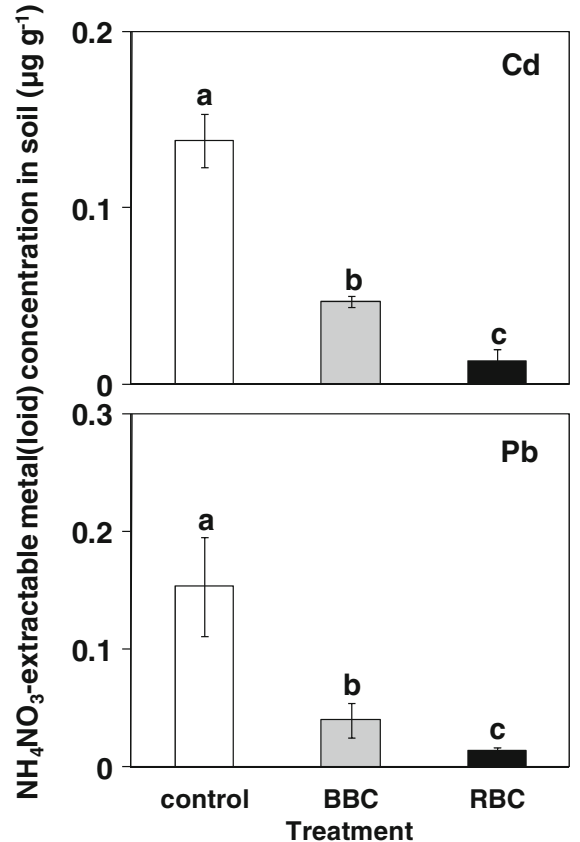

biochar-induced changes to As partioning (the As concentrations in BBC and RBC were 242 and 42 times lower than that in the receiving soil). $\mathrm{RBC}$ treatment resulted in the largest decrease in $\mathrm{NH}_{4} \mathrm{NO}_{3}$-extractable concentrations of soil $\mathrm{Cd}$, $\mathrm{Zn}$, and $\mathrm{Pb}$ and the largest increase in that of As. There was no significant change in As concentration following BBC addition. These changes in metal(loid) extractability are attributed, in part, to changes in $\mathrm{pH}$ following $\mathrm{BC}$ amendment to soil. Soil pH (6.2) was increased to 6.7 (BBC) and 7.4 (RBC) after biochar additions (Table 2). The greater increase in $\mathrm{pH}$ associated with RBC amendment is suggested to have underpinned the greater reduction in $\mathrm{Cd}, \mathrm{Zn}$, and $\mathrm{Pb}$ and the greater increase in As extractability (see later "Discussion").

Metal(loid) and nutrient uptake by rice plant

The formation of iron plaque on the root surface of rice plants was reduced by up to $49.0 \%$ following $\mathrm{RBC}$ amendment, but it was not significantly influenced by BBC amendment (Table 2). Concentrations of $\mathrm{Cd}$ and $\mathrm{Pb}$ in iron plaque were decreased significantly by up to 81.4 and $65.0 \%$, respectively, after BC (especially RBC) amendment, whereas neither BC treatments had a significant effect on concentrations of $\mathrm{Zn}$ and As in iron plaque (Fig. 2).

Biochar amendment decreased concentrations of $\mathrm{Cd}$ and $\mathrm{Zn}$ in rice root by $29.6-74.9 \%$ and $25.0-44.1 \%$, respectively $(p<0.05)$. The largest decrease was observed in the RBC treatment. Root $\mathrm{Pb}$ was significantly decreased by RBC (40.7\%) but not by BBC. Root As concentrations were not changed significantly after BC addition (Fig. 2).

Shoot concentrations of $\mathrm{Cd}$ and $\mathrm{Zn}$ were decreased significantly by $42.9-79.3 \%$ and $19.9-44.2 \%$, respectively $(p<0.05)$, most noticeably in the case of RBC (Fig. 2). Neither of $\mathrm{BC}$ additions caused significant reductions in shoot $\mathrm{Pb}$ concentration with respect to the control, although shoot $\mathrm{Pb}$ concentration in RBC treatment was significantly lower than in $\mathrm{BBC}$ treatment. An increase in shoot As concentration $(34.2 \%)$ occurred in the BBC treatment but not in RBC treatment.

Regarding rice husk and grain, biochar additions significantly decreased $\mathrm{Cd}$ concentrations, but had no significant effects on the concentrations of $\mathrm{Pb}$ and As (Fig. 2; Table 3).

Table 2 Influence of biochar additions on: soil pH, iron plaque formation (DCB-Fe), shoot K and P concentrations, and shoot fresh weight (FW) of rice plants

\begin{tabular}{llllll}
\hline Treatment & Soil pH & $\begin{array}{l}\text { DCB-Fe } \\
\left(\mathrm{mg} \mathrm{g}^{-1} \mathrm{RDW}\right)\end{array}$ & $\begin{array}{l}\text { Shoot K concentration } \\
\left(\mathrm{mg} \mathrm{g}^{-1} \mathrm{DW}\right)\end{array}$ & $\begin{array}{l}\text { Shoot P concentration } \\
\left(\mathrm{mg} \mathrm{g}^{-1} \mathrm{DW}\right)\end{array}$ & $\begin{array}{l}\text { Shoot weight } \\
\left(\mathrm{kg} \mathrm{FW} \mathrm{m}^{-2}\right)\end{array}$ \\
\hline Control & $6.2 \pm 0.06 \mathrm{c}$ & $30.3 \pm 3.0 \mathrm{a}$ & $16.8 \pm 1.7 \mathrm{~b}$ & $1.5 \pm 0.2 \mathrm{~b}$ & $2.60 \pm 0.28 \mathrm{a}$ \\
BBC & $6.7 \pm 0.06 \mathrm{~b}$ & $27.8 \pm 3.6 \mathrm{a}$ & $18.4 \pm 0.7 \mathrm{ab}$ & $1.5 \pm 0.1 \mathrm{~b}$ & $2.78 \pm 0.27 \mathrm{a}$ \\
RBC & $7.4 \pm 0.06 \mathrm{a}$ & $15.5 \pm 1.9 \mathrm{~b}$ & $20.3 \pm 1.4 \mathrm{a}$ & $2.0 \pm 0.1 \mathrm{a}$ & $3.40 \pm 0.79 \mathrm{a}$ \\
\hline
\end{tabular}

Different letters in a same column represent significant difference between treatments $(p<0.05 ; n=4)$ 
Fig. 2 Concentrations of Cd, $\mathrm{Zn}$, $\mathrm{Pb}$ and $\mathrm{As}$ in iron plaque, root, shoot and husk of rice plant (Oryza sativa L.). Un-amended soil (white), BBC treatments (grey), and RBC treatments (black). Different letters above columns indicate significant difference at $p<0.05$ between treatments for the same tissue of rice plant $(n=4)$
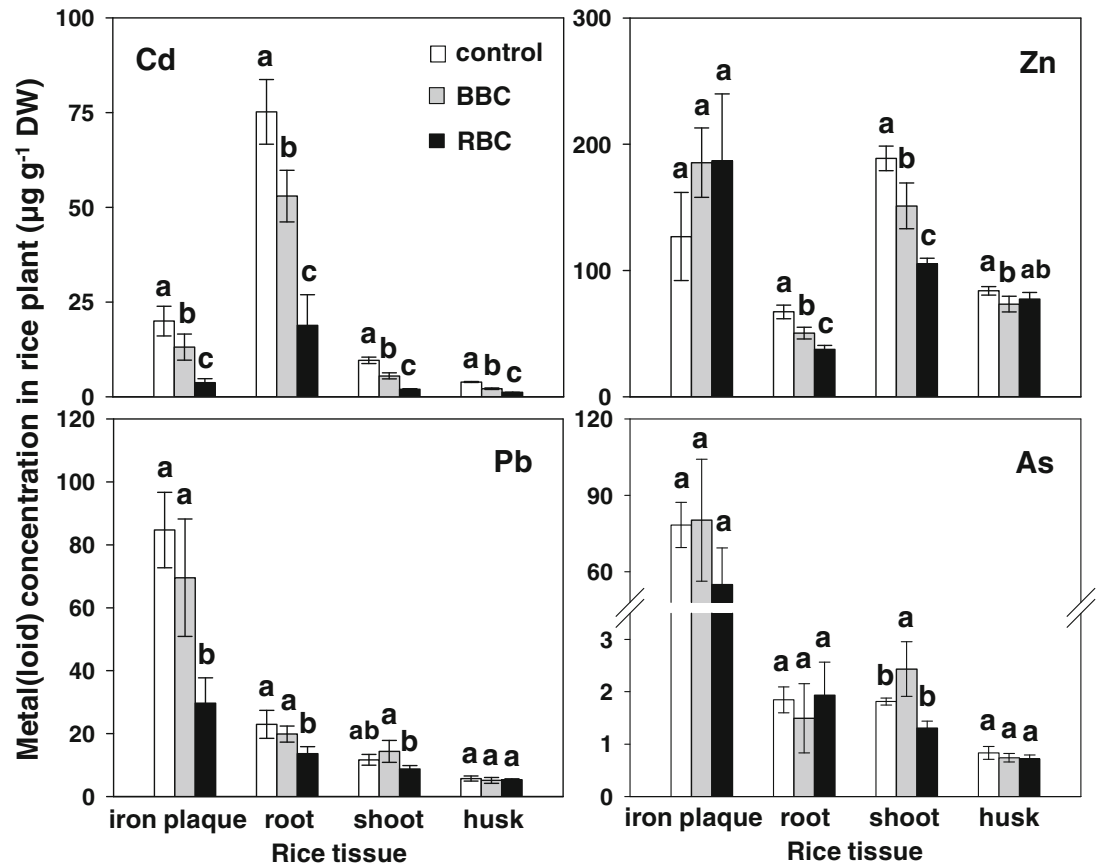

Cd concentrations were decreased by 70.6 and $46.2 \%$ for

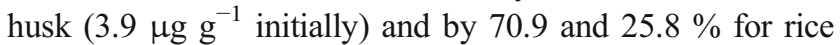
grain $\left(1.8 \mu \mathrm{g} \mathrm{g}^{-1}\right.$ initially) after RBC and BBC amendments, respectively $(p<0.05)$. RBC addition caused larger decreases in $\mathrm{Cd}$ concentration in rice husk and grain than BBC. For $\mathrm{Zn}$, the influence was dependent on $\mathrm{BC}$ type. An increase $(p<0.05)$ in $\mathrm{Zn}$ concentration $(25.1 \%)$ in rice grain was observed following RBC addition, yet no effect was observed in the $\mathrm{BBC}$ treatment. $\mathrm{BBC}$ addition significantly decreased $\mathrm{Zn}$ concentration in husk by $12.5 \%$, but no significant effect was observed following RBC amendment. Cd concentrations in rice grain were 1.6 to 8.0 factors higher than the Chinese regulation limit set for food $\left(0.2 \mu \mathrm{g} \mathrm{g}^{-1}\right)$, but grain As concentrations were below the maximum limit $\left(0.2 \mu \mathrm{g} \mathrm{g}^{-1}\right)$ (Table 3).

For nutrient elements, shoot $\mathrm{K}$ and $\mathrm{P}$ concentrations were increased significantly by 20.3 and $29.6 \%$, respectively, in $\mathrm{RBC}$ but not in BBC treatment (Table 2). Also, BCs increased shoot weights although the increases were not significant statistically $(p>0.05)$.

Estimated daily intake of metal(loid)s and hazard quotients

EDIs and HQs of metal(loid)s are listed in Table 4. EDIs of Zn in soil and both $\mathrm{BC}$ treatments $\left(87-115 \mu \mathrm{g} \mathrm{kg}^{-1}\right.$ day $\left.^{-1}\right)$ were all below the RfD $\left(300 \mu \mathrm{g} \mathrm{kg}^{-1} \mathrm{day}^{-1}\right)$ set by the USEPA, and as a consequence, their HQs were $<1$ (Table 4). After BC addition, $\mathrm{Zn}$ HQ decreased by $5.4 \%$ in the BBC treatments and increased by $25 \%$ in the RBC treatments, but HQs remained well below $1(0.29-0.38)$. EDI for $\mathrm{Pb}$ in the control soil $\left(0.21 \mu \mathrm{g} \mathrm{kg}^{-1} \mathrm{day}^{-1}\right)$ much lower than its RfD $\left(3.5 \mu \mathrm{g} \mathrm{kg}^{-1}\right.$ day $\left.^{-1}\right)$ and, as a consequence, $\mathrm{Pb} \mathrm{HQ}$ was very small (0.06). The addition of BBC and RBC did not alter the EDI or the HQ for $\mathrm{Pb}$. EDI for As in the control soil $\left(0.48 \mu \mathrm{g} \mathrm{kg}^{-1} \mathrm{day}^{-1}\right)$ was higher than RfD $\left(0.3 \mu \mathrm{g} \mathrm{kg}^{-1} \mathrm{day}^{-1}\right)$, and as a consequence, As HQ (1.6)

Table 3 Influence of biochar additions on concentrations of $\mathrm{Cd}, \mathrm{Zn}, \mathrm{Pb}$, and $\mathrm{As}$ in rice grain and grain yield [dry weight (DW)]

\begin{tabular}{llllll}
\hline & \multicolumn{2}{l}{ Metal(loid) in rice grain $\left(\mu \mathrm{g} \mathrm{g}^{-1} \mathrm{DW}\right)$} & Grain weight $\left(\mathrm{kg} \mathrm{DW} \mathrm{m}^{-2}\right)$ \\
\cline { 2 - 5 } & $\mathrm{Cd}$ & $\mathrm{Zn}$ & $\mathrm{Pb}$ & $\mathrm{As}$ & \\
\hline Control & $1.78 \pm 0.29 \mathrm{a}$ & $29.5 \pm 1.9 \mathrm{~b}$ & $0.069 \pm 0.01 \mathrm{a}$ & $0.154 \pm 0.01 \mathrm{a}$ & $0.41 \pm 0.07 \mathrm{a}$ \\
BBC & $1.32 \pm 0.08 \mathrm{~b}$ & $27.9 \pm 2.8 \mathrm{~b}$ & $0.067 \pm 0.01 \mathrm{a}$ & $0.161 \pm 0.01 \mathrm{a}$ & $0.64 \pm 0.18 \mathrm{a}$ \\
RBC & $0.52 \pm 0.03 \mathrm{c}$ & $36.9 \pm 2.9 \mathrm{a}$ & $0.067 \pm 0.01 \mathrm{a}$ & $0.168 \pm 0.01 \mathrm{a}$ & $0.38 \pm 0.08 \mathrm{a}$ \\
CML & $\leq 0.2$ & - & $\leq 0.2$ & $\leq 0.2$ & \\
\hline
\end{tabular}

Different letters in a same column represent significant difference between treatments $(p<0.05 ; n=4)$.

CML Chinese maximum allowable limit of heavy metals in food set by Ministry of Health of the People's Republic of China and Standardization Administration of China (MHPRC and SAC 2012), $0.2 \mu \mathrm{g} \mathrm{g}^{-1}$ for As represents the limit of inorganic arsenic in rice grain 
Table 4 RfD ( $\left.\mu \mathrm{g} \mathrm{kg}^{-1} \mathrm{day}^{-1}\right)$, EDI $\left(\mu \mathrm{g} \mathrm{kg}^{-1} \mathrm{day}^{-1}\right)$, and HQ for individual metal(loid)s associated with the consumption of rice grown in control soils and soils amended with $\mathrm{BBC}$ and $\mathrm{RBC}$

\begin{tabular}{|c|c|c|c|c|c|c|c|}
\hline & \multirow[t]{2}{*}{$\mathrm{RfD}$} & \multicolumn{3}{|l|}{ EDI } & \multicolumn{3}{|l|}{ HQ } \\
\hline & & Control & $\mathrm{BBC}$ & $\mathrm{RBC}$ & Control & $\mathrm{BBC}$ & $\mathrm{RBC}$ \\
\hline $\mathrm{Cd}$ & 1 & 5.5 & 4.1 & 1.6 & 5.54 & 4.11 & 1.62 \\
\hline $\mathrm{Zn}$ & 300 & 92 & 87 & 115 & 0.31 & 0.29 & 0.38 \\
\hline $\mathrm{Pb}$ & 3.5 & 0.21 & 0.21 & 0.21 & 0.06 & 0.06 & 0.06 \\
\hline As & 0.3 & 0.48 & 0.50 & 0.52 & 1.60 & 1.67 & 1.74 \\
\hline
\end{tabular}

Where HQ was $<2$, this has been indicated in italics

exceeded acceptable limits. The addition of BBC and RBC increased EDI (to 0.50 and $0.52 \mu \mathrm{g} \mathrm{kg}^{-1}$ day $^{-1}$, respectively) and HQ (to 1.67 and 1.74 , respectively), but these increases were only trivial (of the order 4.5-9.1\%). The most dramatic changes to EDI and HQ were observed for Cd. Cd EDI in the control soil $\left(5.5 \mu \mathrm{g} \mathrm{kg}^{-1} \mathrm{day}^{-1}\right)$ was greatly in excess of the $\operatorname{RfD}\left(1 \mu \mathrm{g} \mathrm{kg}^{-1} \mathrm{day}^{-1}\right)$, and as a consequence, the Cd HQ (5.5) was well in excess of acceptable levels. Addition of $\mathrm{BBC}$ and $\mathrm{RBC}$ resulted in EDI decreases of 25.8 and $70.8 \%$, respectively. In light of this, Cd HQ saw a modest decrease (to 4.1) in the $\mathrm{BBC}$ treatment and a very pronounced decrease (to 1.6) in the $\mathrm{RBC}$ treatment.

Calculated DF of metal(loid) bioavailability and bioaccumulation

Dynamic factor of metal(loid) bioavailability in soil was showed in Fig. 3a. The $\mathrm{BIO}_{\text {dyn }}$ of soil $\mathrm{Cd}, \mathrm{Zn}$, and $\mathrm{Pb}$ in $\mathrm{BC}$ treatments were all below $1(0.26-0.34)$ though not for that of As (1.08-1.73). The $\mathrm{BIO}_{\text {dyn }}$ of soil $\mathrm{Cd}, \mathrm{Zn}$, and $\mathrm{Pb}$ in $\mathrm{RBC}$ treatment were 70.9, 71.0, and $65.1 \%$ lower than that in $\mathrm{BBC}$ treatment, respectively, whereas that of $\mathrm{As}$ in $\mathrm{RBC}$ was $60.3 \%$ higher than in $\mathrm{BBC}$ amendment. $\mathrm{BA}_{\text {dyn_roots }}$ of $\mathrm{Cd}$, $\mathrm{Zn}, \mathrm{Pb}$, and As were lower than $1(0.70-0.87)$ in $\mathrm{BBC}$ treatment, and only that of As in RBC treatment was $1.04(>1$; Fig. 3b). The $\mathrm{BA}_{\text {dyn_roots }}$ of $\mathrm{Cd}, \mathrm{Zn}$, and $\mathrm{Pb}$ were $64.4,25.5$, and $31.4 \%$ lower in $\mathrm{RBC}$ versus $\mathrm{BBC}$ treatment, but that of As was $29.5 \%$ higher in RBC. After RBC addition, $\mathrm{BA}_{\text {dyn_shoots }}$ of $\mathrm{Cd}, \mathrm{Zn}, \mathrm{Pb}$ and As were all lower than 1 following the sequence of $\mathrm{Cd}<\mathrm{Zn}<\mathrm{As}<\mathrm{Pb}$ (Fig. 3c). The $\mathrm{BA}_{\text {dyn shoots }}$ of $\mathrm{Cd}$ and $\mathrm{Zn}$ were below 1 versus higher than 1 for that of $\mathrm{Pb}$ and $\mathrm{As}$ in $\mathrm{BBC}$ treatment. Comparing with $\mathrm{BBC}$ amendment, $\mathrm{BA}_{\mathrm{dyn} \text { shoots }}$ of $\mathrm{Cd}, \mathrm{Zn}, \mathrm{Pb}$, and $\mathrm{As}$ in $\mathrm{RBC}$ treatment were dramatically lower by $63.8,30.4,39.0$, and $46.5 \%$, respectively. Regarding rice grain, $\mathrm{BA}_{\mathrm{dyn} \text { _grain }}$ of $\mathrm{Cd}$ and $\mathrm{Pb}$ were lower than 1 in both $\mathrm{BC}$ treatments, especially for that of $\mathrm{Cd}(0.29-0.74$; Fig. 3d). Only a slight reduction compared to 1 occurred in $\mathrm{BBC}$ treatment for $\mathrm{BA}_{\mathrm{dyn} \text { grain }}$ of $\mathrm{Zn}$ (0.95). The $\mathrm{BA}_{\mathrm{dyn} \text { grain }}$ of As were larger than 1 in both $\mathrm{BC}$ treatments.

\section{Discussion}

To our knowledge, this is the first investigation of the influence of $\mathrm{BC}$ upon the accumulation of multiple metal(loid)s in rice plants under field conditions. The paddy field herein was historically tainted by multiple metal(loid)s including $\mathrm{Pb}, \mathrm{As}$, $\mathrm{Zn}$, and $\mathrm{Cd}$. $\mathrm{NH}_{4} \mathrm{NO}_{3}$-extractable concentrations of soil $\mathrm{Cd}$,
Fig. 3 Dynamic factors of metal(loid) bioavailability in soil (a), and dynamic factors of metal(loid) bioaccumulation in roots (b), shoots (c), and grain (d) of rice plant. $\mathrm{BBC}$ treatments (grey) and RBC treatments (black). The dashed line indicates the area below which the bioavailability of metal(loid) in soil and concentration of metal(loid) in plant tissues [root (b), shoots (c), and grain (d)] are not higher than those in the control soil
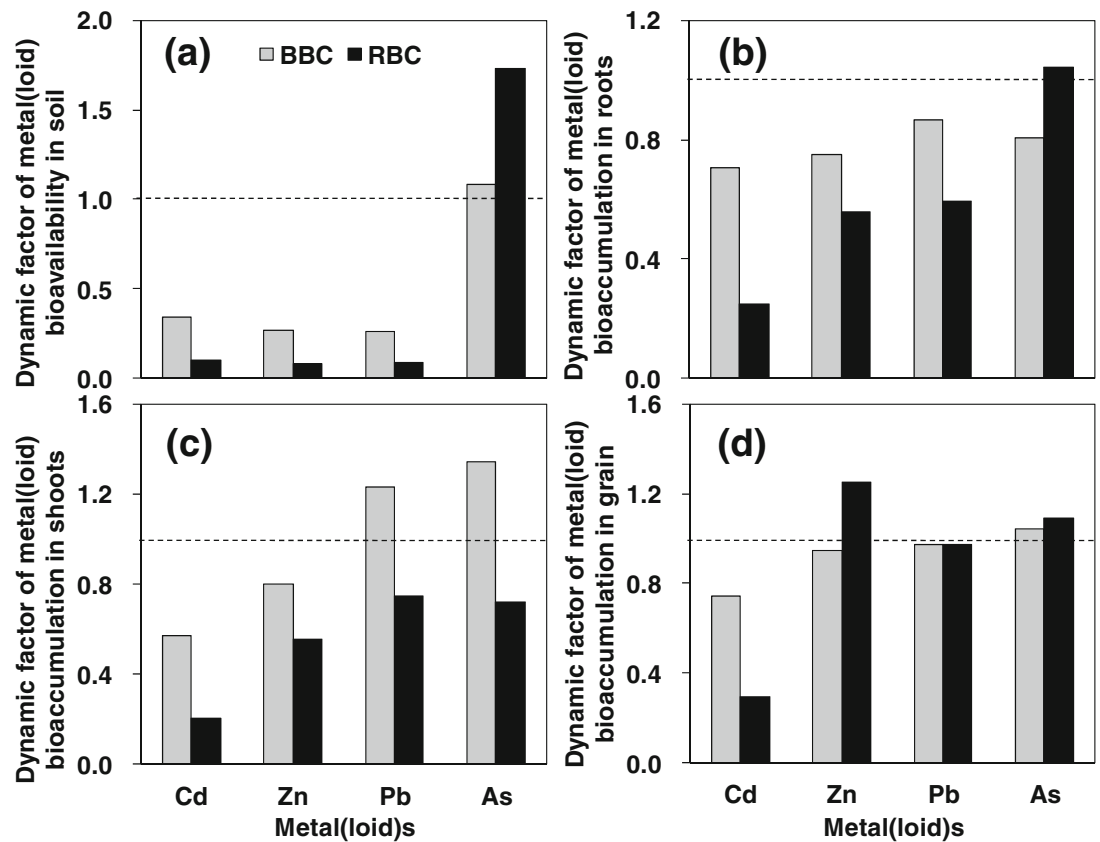
$\mathrm{Zn}$, and $\mathrm{Pb}$ decreased significantly following biochar addition, this was particularly true for RBC (Fig. 1). However, RBC also increased $\mathrm{NH}_{4} \mathrm{NO}_{3}$-extractable concentrations of As (Fig. 1). Potential toxic elements (PTEs; except As) concentrations in rice plant changed by varying degrees after biochar additions; decreases in phytoaccumulation was especially noticeable for Cd (Fig. 2; Table 3).

Soil $\mathrm{pH}$ and $\mathrm{P}$ are suggested to be key factors influencing the decrease in $\mathrm{NH}_{4} \mathrm{NO}_{3}$-extractable concentrations of soil $\mathrm{Cd}, \mathrm{Zn}, \mathrm{Pb}$ and the increase in that of As after biochar addition. The biochar-induced $\mathrm{pH}$ increase $(0.5-1.2$ units) was very important for the immobilization of $\mathrm{Cd}, \mathrm{Zn}$, and $\mathrm{Pb}$ (Fig. 1), which is further supported by a significant correlation existed here between $\mathrm{pH}$ and $\mathrm{NH}_{4} \mathrm{NO}_{3}$-extractable concentrations of soil $\mathrm{Cd}, \mathrm{Zn}$, and $\mathrm{Pb}$ (Fig. 4). Because the number of negatively charged surface sites in soil increases with increasing $\mathrm{pH}$, and the sorption capacity of soil to cationic metals correspondingly increases (Bradl 2004). The $\mathrm{pH}$ increase subsequent to the application of biochar can also reduce metal extractability through promoting metal (co)precipitation as well as metal adsorption on specific biochar mineral phases (Houben et al. 2013; Rees et al. 2014). Finally, there are also other studies showing that metal mobility is reduced in the presence of biochar due to adsorption on the biochar surface (especially on carboxylic and phenolic groups; Uchimiya et al. 2011a, b). On the other hand, a probable increase in the silicon (Si) concentration of soil solution after biochar addition may also contribute to metal immobilization via the formation of silicate precipitates (Houben et al. 2014; Zheng et al. 2012; Gu et al. 2011). A significant increase in Si concentration of soil pore water after biochar (made from rice straw) addition was obtained in our recent study (Zheng et al. 2012). However, Si solubility is not systematically increased in the presence of biochar. Biochar can increase or decrease Si solubility depending on several factors, including feedstocks, application rate, etc. (Houben et al. 2014). The effect of Si on metal immobilization in biochar-amended soils is worth studying. Regarding As, existing as negatively charged oxy-anions, an increase in $\mathrm{pH}$ can decrease the number of positively charged sites in soil and, consequently, lower the sorption capacity (Wilson et al. 2010). Thus, it was reasonable that biochar addition increased $\mathrm{NH}_{4} \mathrm{NO}_{3}$-extractable concentration of As, especially the RBC treatment (Fig. 1; Fig. 4). In addition to an increase in soil $\mathrm{pH}, \mathrm{P}$ entering into soil with biochar application (especially RBC) may also have been a contributing factor in immobilizing $\mathrm{Cd}, \mathrm{Zn}$, and $\mathrm{Pb}$ via the formation of phosphate precipitates (McGowen et al. 2001; Tang et al. 2004) and activating As via competing adsorption onto soil surface with arsenate (Jain and Loeppert 2000). Arsenate retained in soil particles can be desorbed by phosphate and released into soil solution. This process could also accelerate the reduction of arsenate and accordingly increase arsenite concentration in soil solution. Thus, because RBC contained higher P levels than $\mathrm{BBC}$, it may have brought about higher $\mathrm{NH}_{4} \mathrm{NO}_{3}$-extractable concentrations of As (Fig. 1).

The high levels of $\mathrm{Cd}, \mathrm{Zn}, \mathrm{Pb}$, and As contained in iron plaque supports the general consensus that iron plaque has a high adsorption capacity for metal(loid)s (Liu et al. 2006; Lei et al. 2011). However, iron plaque sequestered less $\mathrm{Cd}$ and $\mathrm{Pb}$ after BCs amendment though $\mathrm{Zn}$ and As concentrations in iron plaque were not significantly influenced (Fig. 2). This was likely attributable to the immobilization of $\mathrm{Cd}$ and $\mathrm{Pb}$ in soil as indicated by the decreased $\mathrm{NH}_{4} \mathrm{NO}_{3}$-extractable concentrations (Fig. 1), thus undergoing less transport to the roots.
Fig. 4 Relationship between soil $\mathrm{pH}$ and $\mathrm{NH}_{4} \mathrm{NO}_{3}$-extractable concentrations of $\mathrm{Cd}, \mathrm{Zn}, \mathrm{Pb}$, and As in un-amended soils and BBC and $\mathrm{RBC}$ treatments
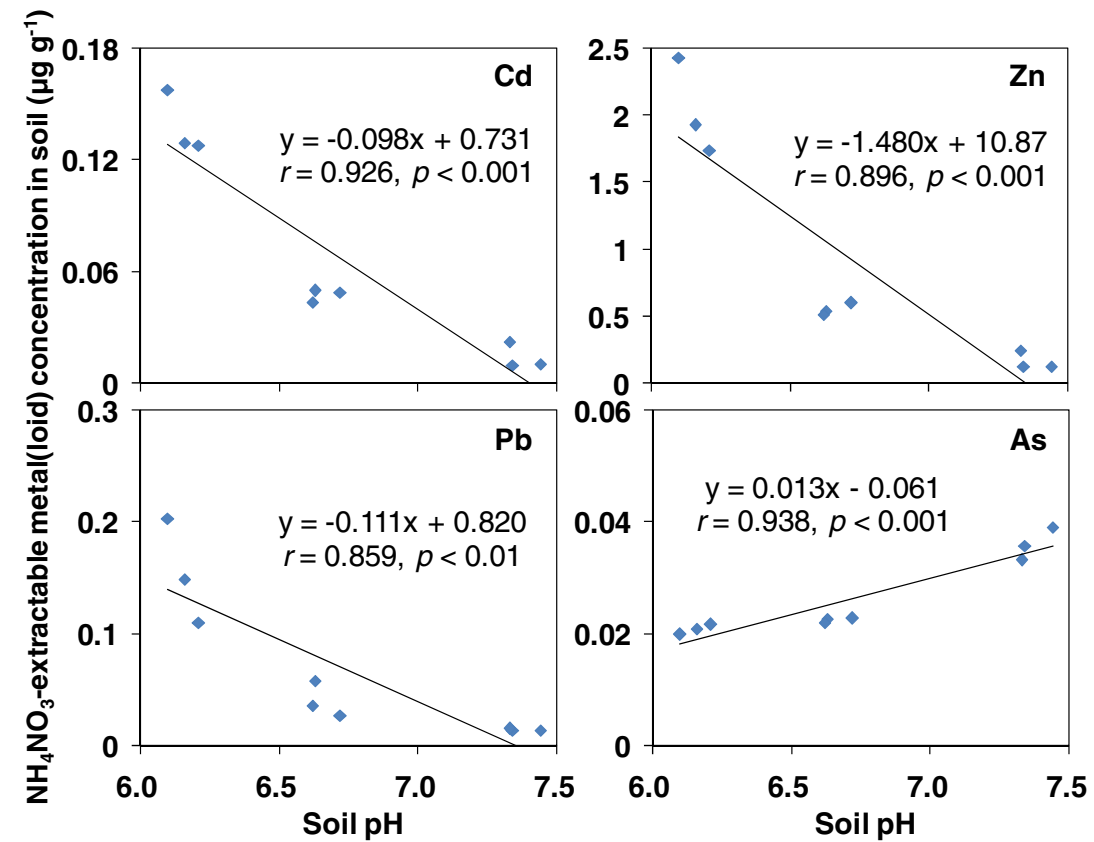
It was hard to explain the insignificant influence on $\mathrm{Zn}$ concentrations of iron plaque despite the decrease of $\mathrm{NH}_{4} \mathrm{NO}_{3}$ extractable $\mathrm{Zn}$ concentration following $\mathrm{BC}$ addition. One possibility was that the adsorption of iron plaque to $\mathrm{Zn}$ was always in a maximum adsorption state due to the particularly high $\mathrm{Zn}$ levels in soil solution. Less iron plaque was formed on root surface after additions of biochar than the control (Table 2). This may be due to the elevated $\mathrm{P}$ concentration following $\mathrm{BC}$ addition. An increase in $\mathrm{P}$ concentration may result in an enhancement of iron phosphate precipitation formation lowering iron mobility in soil solution and/or a reduction in root-oxidizing capacity of rice and retarding the development of iron plaque accordingly (Geng et al. 2005; Fu et al. 2014). The iron plaque may have prevented these metal(loid)s entering into rice plants, although its development was reduced.

Furthermore, biochar can also participate in a variety of biotic and abiotic redox-mediated reactions in soil. Some other studies showed that biochar-derived dissolved organic matter could increase $\mathrm{Fe} / \mathrm{Mn}$ oxide solubilization from soils via reductive dissolution, enhance $\mathrm{Cr}(\mathrm{VI})$ reduction, but promote As(III) oxidation (Dong et al. 2014; Graber et al. 2014; Tong et al. 2014). These redox reactions caused by biochar addition play a considerable role in soil metal(loid)s availability due to potential formation of sulfide precipitation, loss of iron plaque, release of As from Fe/Mn oxide, etc.. These redox process induced by biochar addition and the relevant mechanisms require further studies.

Regarding metal(loid) in plant, $\mathrm{Cd}, \mathrm{Zn}$, and $\mathrm{Pb}$ concentrations in root, shoot, and husk were reduced significantly after biochar addition, RBC caused the largest decrease (Fig. 2). Plant As was slightly influenced by biochar amendment, only shoot As concentration increased in BBC treatment. Reductions in $\mathrm{Cd}$ and $\mathrm{Pb}$ accumulation by Indian mustard after biochar amendment were observed by Park et al. (2011). Similar changes in concentrations of $\mathrm{Cd}, \mathrm{Zn}$, and $\mathrm{Pb}$ in rice shoot influenced by biochar amendment were also observed in our pot experiments previously, yet not in that of As (Zheng et al. 2012). The increased $\mathrm{NH}_{4} \mathrm{NO}_{3}$-extractable concentration of As herein was not translated into the increased As level in rice plant (Fig. 2). This was likely attributed to elevated Si level in rhizosphere competing with As for transporters and preventing As entering into rice root. Arsenite is taken up by rice roots mainly through the $\mathrm{Si}$ uptake pathway (Ma et al. 2008; Zheng et al. 2013b). The only increase in shoot As concentration in $\mathrm{BBC}$ indicated the influenced translocation of As in plant by biochar amendment in keeping with our previous study (Zheng et al. 2012). However, the pathway of As translocation in rice plant involving As sequestration in vacuoles, loading and unloading in xylem and phloem, and reduction or methylation responsible by enzymes remains poorly understood (Zhao et al. 2010). Much further research needs to be undertaken to unravel the mechanisms influencing As translocation in plants.
For concentrations in rice grain, different metal(loid)s had different responses to BCs addition (Table 3). Grain Cd concentration decreased markedly in both $\mathrm{BC}$ treatments; $\mathrm{Pb}$ and As concentrations were not affected significantly; while $\mathrm{Zn}$ concentration slightly increased and decreased in RBC and $\mathrm{BBC}$ treatments, respectively. A decrease in rice grain $\mathrm{Cd}$ concentration (by 16.8-61.9\%) was also reported under biochar amendment at $10-40$ tons $\mathrm{ha}^{-1}$ in a field experiment (Cui et al. 2011). In the present study, grain $\mathrm{Cd}$ concentration reached up to $1.8 \mu \mathrm{g} \mathrm{g}^{-1}$ in rice grown in the control soils; this value being eight times higher than the Chinese maximum allowable limit (CML) of $0.2 \mu \mathrm{g} \mathrm{g}^{-1}$ set by the Ministry of Health of the People's Republic of China and Standardization Administration of China (Table 3). Although still higher than the maximum allowable limit, $\mathrm{Cd}$ concentrations in grain (about $0.5 \mu \mathrm{g} \mathrm{g}^{-1}$ ) biochar additions had decreased grain $\mathrm{Cd}$ concentration by up to $71 \%$. This decrease was greater than that reported by Cui et al. (2011). Grain As concentrations $\left(0.154-0.168 \mu \mathrm{g} \mathrm{g}^{-1}\right)$ in all treatments were lower than the CML of $0.2 \mu \mathrm{g} \mathrm{g}^{-1}$ (Table 3). Furthermore, BC addition resulted in no significant $(p<0.05)$ changes to grain As concentration. This outcome was observed even though available As concentrations in the RBC treatments were observed to significantly $(p<0.05)$ increase (Fig. 1). Linkage between available $\mathrm{Pb}$ concentrations [which change significantly $(p<0.05)$ following $\mathrm{BC}$ addition (Fig. 1)] and grain/husk $\mathrm{Pb}$ concentrations [which did not change significantly (Table 3, Fig. 2) following biochar addition] are likely attributable to the alteration of elemental translocation in plant by biochar treatment (Zheng et al. 2012). Biochar additions, which influenced soil $\mathrm{pH}$, ionic strength, CEC, nutrient level, and microbial activity, can play a key role in plant physiological metabolism indirectly and subsequent elemental translocation. There are abundant $\mathrm{Zn}$ transporters dedicated to $\mathrm{Zn}$ uptake and translocation throughout rice plants (Ishimaru et al. 2011). For Pb, its translocation in plant is restricted to a great extent due to immobilization by the negatively charged pectins within cell wall, precipitation in intercellular space, accumulation in plasma membrane, or sequestration in the vacuoles (Shahid et al. 2012). Thus, only a small fraction of $\mathrm{Pb}$ absorbed by roots can enter into grain.

HQs less than one indicate daily intake of metal(loid)s to be less than the reference dose; this implies an absence of unacceptable risk to human health. The influence of BC upon EDIs and HQs was not standard across the range of metal(loid)s tested. Cd HQ was the most markedly influence by BC decreasing by up to $70.8 \%$, from 5.5 to 1.6 following $\mathrm{RBC}$ addition. Taking an overall average HQ of all metal(loid)s tested suggested a $49 \%$ decrease in HQ following RBC addition. Significantly, the overall HQ was decreased from 1.88 to $<1(0.95$; Table 4$)$.

The values of $\mathrm{BIO}_{\mathrm{dyn}}$ and $\mathrm{BA}_{\mathrm{dyn}}$ below 1 in the present study implied that there were positive effects of reduction on 
metal(loid)s bioavailability in soil and metal(loid)s accumulation in rice roots, shoots, and grain, respectively, caused by $\mathrm{BC}$ additions. The lower $\mathrm{BIO}_{\mathrm{dyn}}$ and $\mathrm{BA}_{\mathrm{dyn}}$ became, the larger effect of reduction biochar treatments made, and vice versa. According to these calculated DFs, the following information can be obtained. Both BC treatments reduced bioavailability of $\mathrm{Cd}, \mathrm{Zn}$, and $\mathrm{Pb}$ by $66.0-90.1 \%, 73.1-92.2 \%$, and 74.1$91.0 \%$, respectively, and increased that of As by $8.1-73.3 \%$, especially in RBC treatment (Fig. 3a). RBC and BBC treatments had positive effects on reduction of metal(loid)s accumulation in roots (except for As in RBC case). The reduction extent in $\mathrm{Cd}, \mathrm{Zn}$, and $\mathrm{Pb}$ were 153.5, 76.2, and 201.3\% larger in RBC treatment than in BBC treatment (Fig. 3b). RBC addition reduced accumulations of $\mathrm{Cd}, \mathrm{Zn}, \mathrm{Pb}$, and $\mathrm{As}$ in shoots by $79.3,44.2,25.0$, and $28.2 \%$, respectively, and had higher effect of shoots metal(loid)s accumulation reduction than BBC. Only $\mathrm{Cd}$ and $\mathrm{Zn}$ accumulation in shoots were reduced under BBC amendment than control (Fig. 3c). Only a marked reduction occurred in grain $\mathrm{Cd}$ accumulation under both $\mathrm{BC}$ treatments. $\mathrm{RBC}$ treatment had a larger reduction effect on grain $\mathrm{Cd}$ accumulation than $\mathrm{BBC}$ (by $173.9 \%$; Fig. 3d). These dynamic factors are dimensionless, thus it is conducive to making comparisons between different treatments easily, or between our data and others in the dynamic factor's way.

The results obtained in the present study are significant as they show potential for $\mathrm{BC}$ to improve food (specifically rice) safety through its ability to mitigate the transfer of metal(loid)s from paddy soil to plant tissues. EDIs and HQ associated with rice consumption can be reduced as a consequence. Considering the important contribution of liming effect to metal immobilization after biochar addition, the interesting results may therefore be limited over time (Houben et al. 2013). Further study is needed to inquire into a long-term effect of biochar on metal immobilization and relevant mechanisms including factors of $\mathrm{pH}$, functional groups, biotic and abiotic surface oxidation in the aging process (Cheng et al. 2006a; Houben et al. 2013; Uchimiya et al. 2011a).

\section{Conclusions}

Both biochar $\mathrm{RBC}$ and $\mathrm{BBC}$ additions effectively immobilized $\mathrm{Cd}, \mathrm{Zn}$, and $\mathrm{Pb}$ in historically multielemental contaminated paddy soil under field conditions. While these additions increased the mobility of soil As, there was no significant increase in concentrations of As in rice grain. Mechanisms affecting plant translocation of As, one of the major contaminants in rice, are badly in need of more research. Of the metal(loid)s considered, BC showed the greatest influence over $\mathrm{Cd}$ availability and its subsequent phytoaccumulation. Grain Cd concentration decreased by up to $71 \%$ after BCs addition. Of the two $\mathrm{BCs}$ assessed $\mathrm{RBC}$ showed the greater potential to reduce $\mathrm{Cd}, \mathrm{Zn}$, and $\mathrm{Pb}$ accumulations in rice plant.
RBC additions successfully decreased overall $\mathrm{HQ}$ from 1.9 to an acceptable level $(<1)$. Given that rice straw is a readily available agricultural residue, we suggest that its conversion to biochar and incorporation into metal(loid), particularly $\mathrm{Cd}$, contaminated soil could be an achievable and cost-effective approach to mitigate metal(loid) exposure associated with rice consumption. In addition, the dynamic factor of metal(loid)s bioaccumulation in plant can be considered as a simple evaluation method to compare effects in chemical element uptake by plants between treatments.

Acknowledgments This work was financially supported by Natural Science Foundation of China (No. 41371459), the National High Technology Research and Development Program of China (863 Program, 2013AA06A209 and 2012AA06A204), and the Foundation for Young Scientists of the Beijing Academy of Agriculture and Forestry Sciences (QNJJ201314).

\section{References}

Abel S, Peters A, Trinks S, Schonsky H, Facklam M, Wessolek G (2013) Impact of biochar and hydrochar addition on water retention and water repellency of sandy soil. Geoderma 202:183-191

Atkinson CJ, Fitzgerald JD, Hipps NA (2010) Potential mechanisms for achieving agricultural benefits from biochar application to temperate soils: a review. Plant Soil 337:1-18

Baltrènaite E, Lietuvninkas A, Baltrènas P (2012) Use of dynamic factors to assess metal uptake and transfer in plants - example of trees. Water Air Soil Pollut 223:4297-4306

Baltrènaite E, Baltrenas P, Butkus D, Lietuvninkas A (2015) Using the dynamic factors method in bioindication and phytoremediation. In: Ansari AA, Gill SS, Gill R, Lanza GR, Newman L (eds) Phytoremediation: management of environmental contaminants, vol 1. Springer, pp 21-30. http://www.springer.com/life+sciences/ ecology/book/978-3-319-10394-5

Beesley L, Moreno-Jimenez E, Gomez-Eyles JL (2010) Effects of biochar and greenwaste compost amendments on mobility, bioavailability and toxicity of inorganic and organic contaminants in a multi-element polluted soil. Environ Pollut 158:2282-2287

Bian R, Chen D, Liu X, Cui L, Li L, Pan G, Xie D, Zheng J, Zhang X, Zheng J, Chang A (2013) Biochar soil amendment as a solution to prevent Cd-tainted rice from China: results from a cross-site field experiment. Ecol Eng 58:378-383

Bradl HB (2004) Adsorption of heavy metal ions on soils and soils constituents. J Colloid Interface Sci 277:1-18

Cheng C-H, Lehmann J, Thies JE, Burton SD, Engelhard MH (2006a) Oxidation of black carbon by biotic and abiotic processes. Org Geochem 37:1477-1488

Cheng F, Zhao N, Xu H, Li Y, Zhang W, Zhu Z, Chen M (2006b) Cadmium and lead contamination in japonica rice grains and its variation among the different locations in southeast China. Sci Total Environ 359:156-166

CNEMC (China National Environmental Monitoring Center) (1990) Background values of soil elements in China, 1st edn. Chinese Environmental Science Press, Beijing (in Chinese)

Cui L, Li L, Zhang A, Pan G, Bao D, Chang A (2011) Biochar amendment greatly reduces rice $\mathrm{Cd}$ uptake in a contaminated paddy soil: a two-year field experiment. Biogeosciences 6:2605-2618 
Dong D, Yang M, Wang C, Wang H, Li Y, Luo J, Wu W (2013) Responses of methane emissions and rice yield to applications of biochar and straw in a paddy field. J Soils Sediments 13:1450-1460

Dong X, Ma LQ, Gress J, Harris W, Li Y (2014) Enhanced Cr(VI) reduction and As(III) oxidation in ice phase: important role of dissolved organic matter from biochar. J Hazard Mater 267:62-70

Fellet G, Marchiol L, Delle Vedove G, Peressotti A (2011) Application of biochar on mine tailings: effects and perspectives for land reclamation. Chemosphere 83:1262-1267

Freddo A, Cai C, Reid BJ (2012) Environmental contextualisation of potential toxic elements and polycyclic aromatic hydrocarbons in biochar. Environ Pollut 171:18-24

Fu YQ, Yang XJ, Shen H (2014) The physiological mechanism of enhanced oxidizing capacity of rice (Oryza sativa L.) roots induced by phosphorus deficiency. Acta Physiol Plant 36:179-190

Geng C, Zhu Y, Liu W, Smith S (2005) Arsenate uptake and translocation in seedlings of two genotypes of rice is affected by external phosphate concentrations. Aquat Bot 83:321-331

Graber ER, Tsechansky L, Lew B, Cohen E (2014) Reducing capacity of water extracts of biochars and their solubilization of soil $\mathrm{Mn}$ and $\mathrm{Fe}$. Eur J Soil Sci 65:162-172

Gu HH, Qiu H, Tian T, Zhan SS, Deng THB, Chaney RL, Wang SZ, Tang YT, Morel JL, Qiu RL (2011) Mitigation effects of silicon rich amendments on heavy metal accumulation in rice (Oryza sativa L.) planted on multi-metal contaminated acidic soil. Chemosphere $83: 1234-1240$

Hale SE, Hanley K, Lehmann J, Zimmerman AR, Cornelissen G (2011) Effects of chemical, biological, and physical aging as well as soil addition on the sorption of pyrene to activated carbon and biochar. Environ Sci Technol 45:10445-10453

Herawati N, Suzuki S, Hayashi K, Rivai IF, Koyama H (2000) Cadmium, copper, and zinc levels in rice and soil of Japan, Indonesia, and China by soil type. Bull Environ Contam Toxicol 64:33-39

Houben D, Evrard L, Sonnet P (2013) Mobility, bioavailability and pHdependent leaching of cadmium, zinc and lead in a contaminated soil amended with biochar. Chemosphere 92:1450-1457

Houben D, Sonnet P, Cornelis J-T (2014) Biochar from Miscanthus: a potential silicon fertilizer. Plant Soil 374:871-882

Ishimaru Y, Bashir K, Nishizawa NK (2011) Zn uptake and translocation in rice plants. Rice 4:21-27

Jain A, Loeppert RH (2000) Effect of competing anions on the adsorption of arsenate and arsenite by ferrihydrite. J Environ Qual 29:14221430

Khan S, Chao C, Waqas M, Arp HPH, Zhu YG (2013) Sewage sludge biochar influence upon rice (Oryza sativa L) yield, metal bioaccumulation and greenhouse gas emissions from acidic paddy soil. Environ Sci Technol 47:8624-8632

Lee JW, Kidder M, Evans BR, Paik S, Buchanan AC, Garten CT, Brown RC (2010) Characterization of biochars produced from cornstovers for soil amendment. Environ Sci Technol 44:7970-7974

Lehmann J (2007) A handful of carbon. Nature 447:143-144

Lei M, Tie B, Williams PN, Zheng Y, Huang Y (2011) Arsenic, cadmium, and lead pollution and uptake by rice (Oryza sativa L.) grown in greenhouse. J Soils Sediments 11:115-123

Li J, Li Y, Wu M, Zhang Z, Lv J (2013) Effectiveness of low-temperature biochar in controlling the release and leaching of herbicides in soil. Plant Soil 370:333-344

Liu WJ, Zhu YG, Smith FA, Smith SE (2004) Do phosphorus nutrition and iron plaque alter arsenate (As) uptake by rice seedlings in hydroponic culture? New Phytol 162:481-488

Liu WJ, Zhu YG, Hu Y, Williams PN, Gault AG, Meharg AA, Charnock JM, Smith FA (2006) Arsenic sequestration in iron plaque, its accumulation and speciation in mature rice plants (Oryza sativa L.). Environ Sci Technol 40:5730-5736
Ma JF, Yamaji N, Mitani N, Xu XY, Su YH, McGrath SP, Zhao FJ (2008) Transporters of arsenite in rice and their role in arsenic accumulation in rice grain. Proc Natl Acad Sci U S A 105:9931-9935

McGowen SL, Basta NT, Brown GO (2001) Use of diammonium phosphate to reduce heavy metal solubility and transport in smeltercontaminated soil. J Environ Qual 30:493-500

Meharg AA, Williams PN, Adomako E, Lawgali YY, Deacon C, Villada A, Cambell RCJ, Sun GX, Zhu YG, Feldmann J, Raab A, Zhao FJ, Islam MR, Hossain S, Yanai J (2009) Geographical variation in total and inorganic arsenic content of polished (white) rice. Environ Sci Technol 43:1612-1617

MHPRC and SAC (2012) Maximum levels of contaminants in foods (GB 2762-2012)

Park JH, Choppala GK, Bolan NS, Chung JW, Chuasavathi T (2011) Biochar reduces the bioavailability and phytotoxicity of heavy metals. Plant Soil 348:439-451

Rees F, Simonnot MO, Morel JL (2014) Short-term effects of biochar on soil heavy metal mobility are controlled by intra-particle diffusion and soil $\mathrm{pH}$ increase. Eur J Soil Sci 65:149-161

Rogan N, Serafimovski T, Dolenec M, Tasev G, Dolenec T (2009) Heavy metal contamination of paddy soils and rice (Oryza sativa L.) from Kočani Field (Macedonia). Environ Geochem Health 31:439-451

Shahid M, Pinelli E, Dumat C (2012) Review of Pb availability and toxicity to plants in relation with metal speciation; role of synthetic and natural organic ligands. J Hazard Mater 219:1-12

Sun GX, Williams PN, Carey AM, Zhu YG, Deacon C, Raab A, Feldmann J, Islam RM, Meharg AA (2008) Inorganic arsenic in rice bran and its products are an order of magnitude higher than in bulk grain. Environ Sci Technol 42:7542-7546

Tang XY, Zhu YG, Chen SB, Tang LL, Chen XP (2004) Assessment of the effectiveness of different phosphorus fertilizers to remediate $\mathrm{Pb}$ contaminated soil using in vitro test. Environ Int 30:531-537

Taylor GJ, Crowder AA (1983) Use of DCB technique for extraction of hydrous iron oxides from roots of wetland plants. Am J Bot 70: $1254-1257$

Tong H, Hu M, Li FB, Liu CS, Chen MJ (2014) Biochar enhances the microbial and chemical transformation of pentachlorophenol in paddy soil. Soil Biol Biochem 70:142-150

Uchimiya M, Chang S, Klasson KT (2011a) Screening biochars for heavy metal retention in soil: role of oxygen functional groups. J Hazard Mater 190:432-441

Uchimiya M, Wartelle LH, Klasson KT, Fortier CA, Lima IM (2011b) Influence of pyrolysis temperature on biochar property and function as a heavy metal sorbent in soil. J Agric Food Chem 59:2501-2510

USEPA (2014) Integrated risk information system-database, Philadelphia PA, Washington, DC. http://www.epa.gov/iris/

Uzoma KC, Inoue M, Andry H, Fujimaki H, Zahoor A, Nishihara E (2011) Effect of cow manure biochar on maize productivity under sandy soil condition. Soil Use Manag 27:205-212

Wang Q, Dong Y, Cui Y, Liu X (2001) Instances of soil and crop heavy metal contamination in China. Soil Sediment Contam 10:497-510

Williams PN, Lei M, Sun GX, Huang Q, Lu Y, Deacon C, Meharg AA, Zhu YG (2009) Occurrence and partitioning of cadmium, arsenic and lead in mine impacted paddy rice: Hunan, China. Sci Total Environ 43:637-642

Wilson SC, Lockwood PV, Ashley PM, Tighe M (2010) The chemistry and behaviour of antimony in the soil environment with comparisons to arsenic: a critical review. Environ Pollut 158:1169-1181

Yuan JH, Xu RK, Zhang H (2011) The forms of alkalis in the biochar produced from crop residues at different temperatures. Bioresour Technol 102:3488-3497

Zhang A, Liu Y, Pan G, Hussain Q, Li L, Zheng J, Zhang X (2012) Effect of biochar amendment on maize yield and greenhouse gas emissions from a soil organic carbon poor calcareous loamy soil from Central China Plain. Plant Soil 351:263-275 
Zhao FJ, McGrath SP, Meharg AA (2010) Arsenic as a food chain contaminant: mechanisms of plant uptake and metabolism and mitigation strategies. Annu Rev Plant Biol 61:535-559

Zheng RL, Cai C, Liang JH, Huang Q, Chen Z, Huang YZ, Arp HPH, Sun GX (2012) The effects of biochars from rice residue on the formation of iron plaque and the accumulation of $\mathrm{Cd}, \mathrm{Zn}, \mathrm{Pb}, \mathrm{As}$ in rice (Oryza sativa L.) seedlings. Chemosphere 89:856-862
Zheng H, Wang Z, Deng X, Herbert S, Xing B (2013a) Impacts of adding biochar on nitrogen retention and bioavailability in agricultural soil. Geoderma 206:32-39

Zheng RL, Sun GX, Zhu YG (2013b) Effects of microbial processes on the fate of arsenic in paddy soil. Chin Sci Bull 58:186-193

Zhu YG, Williams PN, Meharg AA (2008) Exposure to inorganic arsenic from rice: a global health issue? Environ Pollut 154:169-171 